\title{
Kinanthropometric Profile of Beach Volleyball Player of Category under 19 and under 21 of European Championship 2015
}

\author{
Julio Cesar de Faria Pastore ${ }^{1,2,4}$, Carlos Alberto de Azevedo Ferreira ${ }^{1,2,4}$, Fabíola \\ Claudia Henrique da Costa ${ }^{3,4}$, Paulo Vicente João ${ }^{4}$ \\ ${ }^{1}$ Physical Education, Estácio de Sá University - Rio de Janeiro - Brazil \\ ${ }^{2}$ Laboratory of Physiology of Exercise \& Measurements and Evaluation (LAFIEX), Estácio de Sá \\ University - Rio de Janeiro - Brazil \\ ${ }^{3}$ HEMORIO - State Institute of Hematology " Arthur de Siqueira Cavalcanti " - Rio de Janeiro - \\ Brazil \\ ${ }^{4}$ Research Center in Sports Science, Health and Human Development (CIDESD), University of Tras- \\ os-Montes and Alto Douro - Vila Real - Portugal \\ juliocesar.pastore@gmail.com
}

\begin{abstract}
Athletes in general are widely discussed in the scientific literature, height as well as the somatotype is particularly important in beach volleyball, because the absolute size contributes significantly in the percentage of the total variance associated with athletic success. Kinanthropometric describes the profile of high performance beach volleyball players in the categories under 19 and under 21 by functions. The measures were assessed body composition, somatotype, proportionality and several anthropometric indicators in nine volleyball players, grouped by function in the game. All athletes members of the national team in Europe who participated in the World Games in Europe (2015) in their respective categories. The means and standard deviations were calculated for the entire study. Analysis of variance was used to compare the averages for different functions as well as to the body mass, height, fat mass, residual, muscle and bone and body mass index. The discriminate analysis was performed to identify differentiating anthropometric variations in function within the game (defending and blocking), using $p<0.05$ as significance threshold. The blockers had higher height $(182 \pm 0.0 \mathrm{~cm})$, adiposity $(11.41 \pm 1.6 \mathrm{~kg})$, muscle mass $(52.08 \pm 2.5 \mathrm{~kg})$ and $\%$ fat $(16.6 \pm 1.6 \mathrm{~kg})$. The average somatotype of all players was ectomorph. Classified by function, the blocking had an endo-ectomorph somatotype and meso-ectomorph defenders. The kinanthropometric profile of volleyball players was considered to international standards, with a predominantly somatotype mesomorph-ectomorph. The height and body composition varied within the proportions of his duties.
\end{abstract}

Keywords: Body composition, somatotype, volleyball, anthropometry

\section{INTRODUCTION}

In beach volleyball over the years, we observe the evolution of anthropometric variables on high yield, where the teams are similar and other variables are seen to be relevant MASSA ${ }^{1}$. It has been seen that the kinanthropometric characteristics of adult and youth teams has changed as the strategic changes in the game.

Anthropometric characteristics and morphological parameters are extremely important indicators to determine the success of an athlete (Koley et al..$^{2}$ Elaheh et al. ${ }^{3}$; Bozo and Lleshi ${ }^{4}$; Bianchini et al. ${ }^{5}$ ). These features, in combination with studies on physiological area, has been increasingly subject to studies, particularly the last two decades (GABBETT ${ }^{6}$; MILIC et al. ${ }^{7}$ ).

Some authors description in their studies, a number of anthropometric and physical characteristics (height, body weight, \% body fat and somatotype) as well as physical performance parameters, seems

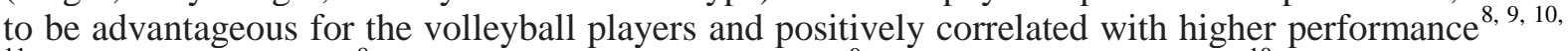
${ }^{11}$ ( ESCUDERO et al. ${ }^{8}$, ANZA, DENIS and SILVA ${ }^{9}$; MALOUSARIS et al . ${ }^{10}$; LEVANDOSKI , CARDOSO and CLESLAK ${ }^{11}$ ) .

Nevertheless, despite the popularity of this sport in the world, the search for variables that identify who the future athlete still in the initiation has been a challenge to the researchers, there are particularly those related to adolescent females and young people from different ages (DUNCAN et al. ${ }^{12}$ ). 
The aim of the study was to describe in kinanthropometric terms, the profile of European women's volleyball athletes involved in different stages of the promotion of talent process. For this, we used a sample of nine athletes from high competitive level of the categories under 19 and under 21 (19 \pm 0.8$)$ of a training center in Europe.

\section{MethodS}

The study was characterized as descriptive field (Thomas Nelson and Silverman ${ }^{13}$ ). In data collection, standardization was adopted the "International Society for the Advancement of Kinanthropometry" 14 (ISAK, 2011) recording the height, body mass (BM), skin fold thickness (S), body circumferences (BC) and diameter bone (DB). Anthropometric evaluation was used the mathematical model for the body density of women developed by Jackson \& Pollock ${ }^{15}$, the equation of Siri (1961), the percentage of body fat and body mass index (BMI). To measure the body mass and height was used a portable digital scale anthropometric (Plenna®, Brazil) and a portable stadiometer (Sanny®, Brazil), respectively. In measuring the skinfolds was used the scientific compass (Lange® USA), the perimeters a metal tape measure anthropometric (Sanny®, Brazil) and breadths the caliper (Sanny®, Brazil). The somatotype was determined by the equation of Heath \& Carter ${ }^{16}$. Additionally, all measurements performed were measured by the same appraiser, certified anthropometrist Level One by the International Society for the Advancement of Kinanthropometry (ISAK). Data analysis was performed descriptive statistics showing the mean values and standard deviation, and the verification of the normality of the data, according to results of normality test was performed an inferential analysis with Studant " $t$ " Test for independent samples, where it was established as the mean test value of $\mathrm{p}<0.05$. All statistical analysis was performed using the SPSS v.22, Microsoft Excel v.2007. The study was approved by the Research Ethics Committee Involving Human Subjects of the Estácio de Sá University on 10/22/2010 under the Protocol FR 368879. All subjects received oral explanations and written and participated in the study after signing the term consent had a track given to the participant.

\section{Results}

Table1. Description of Anthropometric Athletes by Function

\begin{tabular}{|c|c|c|c|c|}
\hline \multirow[t]{2}{*}{ Athletes } & \multicolumn{2}{|c|}{ Defender } & \multicolumn{2}{|c|}{ Blocker } \\
\hline & Mean & S.D. & Mean & S.D. \\
\hline \multicolumn{5}{|c|}{ Basic Variables } \\
\hline Age (year) & 18.0 & 0.4 & 19.0 & 1.0 \\
\hline Weight $(\mathrm{kg})$ & 63.1 & 0.2 & 68.2 & 4.1 \\
\hline Stature $(\mathrm{cm})$ & 175 & 0.0 & 182 & 0.0 \\
\hline \multicolumn{5}{|l|}{ Diameter (cm) } \\
\hline Bi-Styloid & 5.6 & 0.2 & 5.7 & 0.2 \\
\hline Bi-Humeral & 6.3 & 0.1 & 6.4 & 0.5 \\
\hline Bi-Femoral & 9.1 & 0.2 & 9.5 & 0.3 \\
\hline Bi-Malleolus & 7.1 & 0.3 & 7.4 & 0.2 \\
\hline \multicolumn{5}{|c|}{ Perimeter $(\mathrm{cm})$} \\
\hline Chest & 80.9 & 2.3 & 83.9 & 2.5 \\
\hline Abdomen & 74.1 & 2.4 & 81.7 & 4.2 \\
\hline Right arm & 27.6 & 0.4 & 27.9 & 1.6 \\
\hline Left arm & 26.7 & 0.3 & 27.5 & 1.7 \\
\hline Right thigh & 56.3 & 1.3 & 56.6 & 3.7 \\
\hline Left thigh & 55.8 & 0.9 & 56.3 & 3.2 \\
\hline Right leg & 35.3 & 1.8 & 35.9 & 2.6 \\
\hline Left leg & 35.4 & 1.3 & 36.2 & 2.5 \\
\hline \multicolumn{5}{|l|}{ Skinfold (mm) } \\
\hline Chest & 4.8 & 0.7 & 5.4 & 0.9 \\
\hline Axillary & 6.0 & 1.0 & 7.8 & 2.0 \\
\hline Subscapularis & 7.1 & 0.7 & 8.4 & 1.2 \\
\hline Triceps & 12.7 & 2.4 & 13.8 & 0.8 \\
\hline Supra-iliac & 8.2 & 1.0 & 10.8 & 2.3 \\
\hline Abdomen & 9.0 & 1.5 & 14.8 & 2.3 \\
\hline Thigh & 16.0 & 3.6 & 18.8 & 2.1 \\
\hline Leg & 4.5 & 0.3 & 5.2 & 0.7 \\
\hline
\end{tabular}

Legend: S.D. (standard deviation) 
When performing the assessment comparing the anthropometric profile between the players, blocker and defender, within the group, we observed a significant difference $(p<0.05)$ both in stature and in perimeter of athletes. The blockers athletes presented a profile of higher stature than the defenders. Abdominal girth also showed a significant difference $(\mathrm{p}<0.05)$ between the athletes, being a major estimated value for the blocker. However, the other results analyzed did not provide significant differences among athletes evaluated (Table 1).

Table2. Body Composition, Anthropometric Indices and Somatotype of Athletes by Function

\begin{tabular}{|c|c|c|c|c|}
\hline \multirow{2}{*}{$\begin{array}{l}\text { Athletes } \\
\text { Indicators }\end{array}$} & \multicolumn{2}{|c|}{ Defender } & \multicolumn{2}{|c|}{ Blocker } \\
\hline & Mean & S.D. & Mean & S.D. \\
\hline \multicolumn{5}{|l|}{ Fat Mass } \\
\hline Percentage (\%) & 13.8 & 1.5 & 16.5 & 1.4 \\
\hline Weight (kg) & 8.80 & 0.9 & 11.41 & 1.6 \\
\hline Z-score & 5.9 & 2.5 & 3.5 & 2.8 \\
\hline \multicolumn{5}{|l|}{ Muscle Mass } \\
\hline Percentage (\%) & 85.2 & 1.5 & 82.5 & 1.5 \\
\hline Weight (kg) & 49.81 & 1.0 & 52.08 & 2.5 \\
\hline Z-score & 9.3 & 0.2 & 4.2 & 1.6 \\
\hline \multicolumn{5}{|l|}{ Somatotype } \\
\hline Endomorph & 2.8 & 0.4 & 3.2 & 0.3 \\
\hline Mesomorph & 3.0 & 0.7 & 2.5 & 1.2 \\
\hline Ectomorph & 3.6 & 0.4 & 4.1 & 0.9 \\
\hline \multicolumn{5}{|l|}{ Indexes } \\
\hline$\sum$ of 6 Skinfold & 44.00 & 0.6 & 44.60 & 1.2 \\
\hline$\sum$ of 7 Skinfold & 64.00 & 8.6 & 79.80 & 9.7 \\
\hline BMI $\left(\mathrm{kg} / \mathrm{m}^{2}\right)$ & 20.6 & 0.5 & 20.6 & 1.4 \\
\hline
\end{tabular}

Legend: S.D. (Standard Deviation) $\Sigma$ (Sum), Body Mass Index (BMI)

For verification of the proportionality of fat mass, muscle, bone and residual of athletes was used the Phantom strategy developed by Ross and Ward ${ }^{17}$, height is $170,18 \mathrm{~cm}$ for standardizing and correcting the value of the body weight for that height difference of athletes.

By performing this process was identified that in both the defenders athletes groups have higher amounts of fat, less muscle and higher residual mass than blockers athletes, and in the bone approximately the group had the same proportionality (Table 2).

By observing the group of BMI data was found that there was no significant difference, the same prevailing for the sum of 6 skin fold, however, for the sum of 7 skin fold, the defenders had a lower average than the blockers (Table 2).

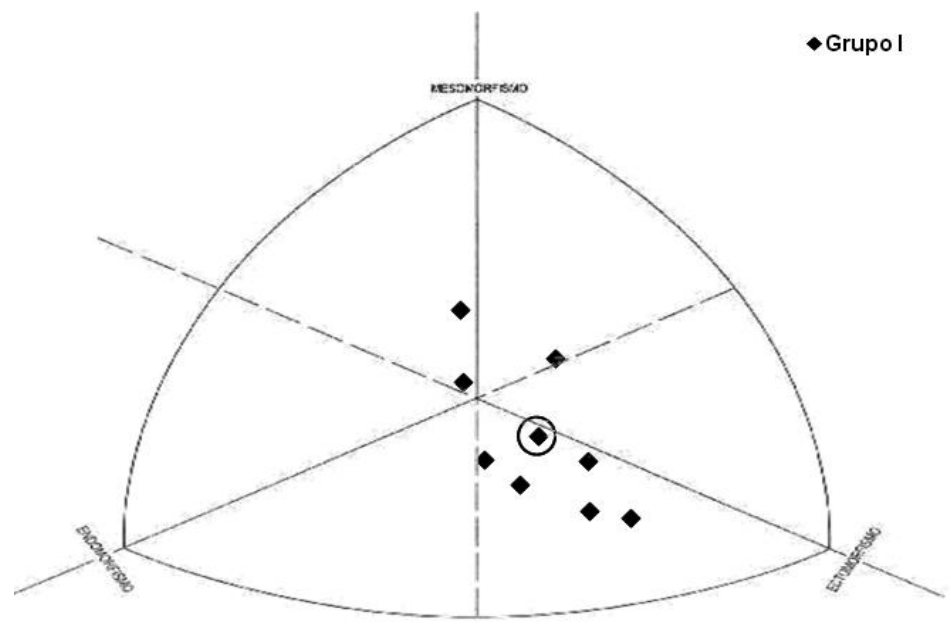

Figure1. Somatotype Athletes Group

The somatotype graphic shows the location of the 9 measured athletes. How can emphasize the distribution of blocker $(n=5)$ presented somatotype endo-ectomorph and defenders $(n=4)$ ecto- 
mesomorph. However, the average somatotypic group is characterized as ( 3.0,2.7,3.9) ectoendomorph (Figure 1).

\section{DisCUSSION}

The lack of published research in areas relevant to the applied sciences in women's volleyball has been offset by many more studies in traumatology area and neuromuscular physiology (Lidor and $\mathrm{Ziv}^{18}$ ). Given the lack of studies on women's beach volleyball players, the study is the proposal to equip anthropometric references and somatotypical to serve as a starting point for further studies on the subject.

In volleyball height is considered as one of the most important physical attributes and other anthropometric data, knowing that the athletes need to overcome the height of the net which is $2.24 \mathrm{~m}$. In the recent study, the group of athletes showed the stature of $(1.79 \pm 0.04 \mathrm{~m})$, this being higher than the Spanish $(169.84 \pm 6.46)$ cited in the study Escudero et $\mathrm{al}^{8}$, top of the female elite athletes Iraqi $(178.70 \pm 18.11)$ Elaheh et al. ${ }^{3}$ greater than Albania players being $(n=24)$ of elite time $(177.2 \pm 7.61)$ $(n=8)$ of the local time $(176.2 \pm 5.31)$, and $\quad(n=7)$ of the university team $(175.2 \pm 4.07)$ compared to the study of Bozo and Lleshi ${ }^{4}$, the same was observed in relation to the 25 college players in India which showed $(159.67 \pm 5.85)$ in the study (KOLEY and SANDHU ${ }^{2}$ ).

When confronted to the study of Anza, Denis and Silva ${ }^{9}$, who evaluated 19 girls aged 14-17 years, have observed that the height $(171.78 \pm 9.28)$ is below the proposed study.

In the study of Bianchini et al. ${ }^{5}$ is the same situation with a view that the 7 beach volleyball athletes had a lower height $(1.72 \pm 4.4)$ than those evaluated in this study.

Scientific studies in sports reveal that somatotypical peculiarities vary according to the sport, the level of qualification and playing position, and this qualification de fined by results at the international level (FIVB ${ }^{19}$ ).

Concomitantly, the somatotype of this study in different playing positions (defenders and blockers) revealed a profile specific for each function where the defenders were classified as ecto-mesomorfa $(2.8,3.0,3.6)$, and blockers as ecto-endomorfa $(3.2,2.5,4.1)$ which differs classication found by Duncan et al. ${ }^{12}$ where evaluated twenty-five youth athletes court volleyball aged 16-19 (17.5 \pm 0.5$)$. For network means players considered the highest, somatotype presented ecto-mesomorph characteristics and the attackers, with lower ectomorphy characteristics.

Levandoski et al. ${ }^{11}$, in a study with 11 female athletes noted that the athletes showed somatotypical profile with average values of endo-ectoformia $(4.7,3.3,4.5)$ corroborating the present study, where the average values presented itself as ecto-endomorph $(3.0,2.7,3.9)$.

A study by Malousaris et al. ${ }^{10}$ the result was distinguished with the findings in this study, it was identified the somatotype profile of the Greek players alloy Al and A2 national, with the characteristic endomorphy $(3.4,2.7,2.9)$.

Milic et al. ${ }^{7}$ quotes in their study with 114 children and young athletes female so distributed: $(n=61)$ of (1st to 4th) and ( $n=53)$ of the (5th to 8th place) of the Croatian national league rankings, verified that the best placed presented characteristics $(4.1,2.6,3.8)$ and $(4.6,2.9,3.4)$ respectively.

\section{Conclusion}

Considering the objectives of this study, we analyze the athletes presented, how much height, values close to those expected for the high competitive level volleyball athletes. Thus, we emphasize that the sport selection process in the women's volleyball, has its own anthropometric characteristics that pointed to the choice of young people with high stature and linearity.

Comparing the somatotypical values, it was found that the values were heterogeneous with respect to other athletes from different countries. The results of this study can serve as a parameter for the selection of beach volleyball athletes and training of this population monitoring. We hope the information in this research offer to coaches and trainers references for the sport, as well as, indicators to characterize the level of qualification of the athletes on their roles in court. We suggest that supplementary studies be carried out, which could greatly contribute to the development of beach volleyball. 


\section{REFERENCES}

[1] Massa M. Seleção e promoção de talentos esportivos em voleibol masculino: análise de aspectos cineantropométricos. Dissertação (Mestrado). São Paulo (SP): Universidade de São Paulo, São Paulo: Escola de Educação Fisica e Esporte; 1999.

[2] Koley S, Singh J, Sandhu JS. Anthropometric and physiological characteristics on Indian interuniversity volleyball players. journal of human sport \& exercise. 2010;5.

[3] Elaheh K, Farzaneh M, Narges G, Mahdieh G. Describing the body composition and some anthropometric features of elite female volleyball students. Res. J. Sport. Sci. Vol. 2013:1:35-40.

[4] Bozo D, Lleshi E. Comparison of albanian female volleyball player with anthropometric, performance and haematological parameters. Journal of human sport \& exercise. 2012;7.

[5] Bianchini L, Brandão A, Liberali R, Navarro F. Analise da diferença nas circunferências de membros inferiores e superiores de atletas de voleibol de praia do estado de santa catarina. Revista Brasileira de Prescrição e Fisiologia do Exercício. 2011;30:548-553.

[6] Gabbett TJ. Physiological and anthropometric characteristics of amateur rugby league players. Br J Sports Med. 2000; 34:303-307.

[7] Milic M, Grgantov Z, Katic. R. Somatotype of young female volleyball players. Exercise and quality of life. 2012;4:7-14.

[8] Escudero MEG, Montesdeoca SS, Martín AP, Ruiz DR, Manso JG. Características antropométricas de los jugadores españoles de voley playa. Comparación por categorías. Int. J. Morphol. 2014;32:22-28.

[9] Anza R, Denis M, Silva MF. Analysis of physical fitness, anthropometry and prevalence of musculoskeletal symptoms in the youth volleyball category. Rev Bras Med Esporte . 2013;19.

[10] Malousaris GG, Bergelesa NK, Barzoukaa KG, Bayiosa I.A, Nassisb. GP, Koskoloub MD. Somatotype, size and body composition of competitive female volleyball players. Journal of Science and Medicine in Sport. 2008; 11:337-344.

[11] Levandoski G, Cardoso FL, Cleslak F. Perfil somatótipo, variáveis antrométricas, aptidão física e desempenho motor de atletas juvenis de voleibol feminino de ponta Gorssa. Fit Perf. J. 2007; $6: 310$.

[12] Duncan MJ, Woodfield L, al-Nakeeb Y. Anthropometric and physiological characteristics of junior elite volleyball players. Br J Sports Med. 2006;40:649-651.

[13] Thomas RJ, Nelson KJ, Silverman SJ. Métodos de pesquisas em atividade física. $5^{\text {a }}$ ed. Porto Alegre: Artmed; 2007.

[14] Marfell-Jones, M. J., Olds, T., Stewart, A. D., \& Carter, L. International standards for anthropometric assessment. International Society for the Advancement of Kinanthropometry (ISAK), Potchefstroom, South Africa: 2006a

[15] Jackson AS, Pollock ML. Generalized equations for predicting body density of men. British Journal of Nutrition. 1978; 40:497-504.

[16] Heath BH and Carter JE. Somatotyping: development and applications, 1st edn. NY: Cambridge Univ. Press; 1990.

[17] Ross, W. D. \& Ward, R. The O-scale system, Surrey. B.C: Rosscraft, 1985

[18] Lidor R, Ziv G. Physical and physiological attributes of female volleyball players--a review. J.Strength Cond Res. 2010; 24:1963-73.

[19] FIVB. Federação Internacional de Voleibol. Volleyball competitions youth women. 2013. Disponível em: http://www.fivb.org. 2015. 